\title{
Penentuan Jadwal dan Rute Perjalanan Kapal dengan Batasan Waktu dan Jumlah Kunjungan
}

\author{
I Gede Agus Widyadana ${ }^{1 *}$, Richard Wibisono ${ }^{1}$
}

\begin{abstract}
Scheduling and routing are important for a shipping company. In this paper a scheduling and routing model is developed to solve a shipping company problem. The model is different to some previous models since it considers the company's constraints such as number of ports that can be visited in one route, number of calls in each port and minimum gap between consecutive visits. The model is applied in one shipping company in Surabaya, Indonesia and is solved using insertion heuristic and simulated annealing. The result shows that simulated annealing method can reduce $18.2 \%$ of total distance compare to previous company's schedule and routes.
\end{abstract}

Keywords: Ship scheduling; vehicle routing problem; insertion heuristic; simulated annealing.

\section{Pendahuluan}

Penentuan rute kapal merupakan perencanaan urutan pelabuhan yang akan dikunjungi suatu kapal sedangkan istilah penjadwalan digunakan jika waktu kunjungan dan keberangkatan kapal juga dipertimbangkan. Pada umumnya ada batasan waktu kapan kapal harus mengunjungi suatu pelabuhan. Penelitian mengenai penjadwalan dan penentuan rute perjalanan kapal merupakan suatu yang penting dan menjadi fokus penelitian yang terus berkelanjutan. Christiansen et al. [1] memberikan perspektif penelitian di bidang penjadwalan dan penentuan rute perjalanan kapal dengan melakukan studi literatur pada lebih dari 60 literatur. Keputusan yang dibuat pada penelitian yang pernah dilakukan diantaranya adalah penentuan jadwal bongkar muat, dan penentuan rute. Metode yang pernah digunakan dalam penelitian terdahulu diantaranya pemrograman dinamis, simulasi dan pemrograman linier. Christiansen et al. [2] melanjutkan studi literatur yang dilakukan di awal dengan memasukkan literatur yang lebih baru pada penelitian yang sudah dilakukan dan melakukan studi dengan lebih rinci. Penelitian mengenai penentuan rute dan penjadwalan diselesaikan dengan beberapa metode heuristik dan metaheuristik untuk dapat menyelesaikan permasalahan di dunia nyata yang lebih kompleks. Bronmo et al. [3] menggunakan model pemrograman integer untuk menentukan rute dan jadwal kapal dengan batasan waktu dan ukuran kargo yang fleksibel. Model mereka diujicobakan dengan menggunakan 8 kasus dengan maksimum waktu pelayaran 120 hari, jumlah kargo 17 dan jumlah kapal sebanyak 7 buah.

${ }^{1}$ Fakultas Teknologi Industri, Program Studi Teknik Industri, Universitas Kristen Petra, Jl. Siwalankerto 121-131 Surabaya, 60236, Indonesia. Email: gede@petra.ac.id.
* Penulis korespondensi

Metode yang digunakan akan membutuhkan waktu penyelesaian yang lama jika diaplikasikan pada kasus nyata. Korsvik et al. [4] membuat model penentuan jadwal dan rute kapal dengan menggunakan batasan waktu dengan menggunakan Tabu Search sebagai salah satu metode metaheuristik. Mereka menyimpulkan bahwa metode metaheuristik yang mereka gunakan menghasilkan nilai yang lebih baik dari metode pencarian lokal dari penelitian sebelumnya. Agarwal dan Ergun [5] membangun model penyelesaian penjadwalan dan penentuan rute kapal dengan menggunakan metode mixed integer programming. Untuk melakukan efisiensi perhitungan, mereka menyelesaikan model dengan menggabungkan metode greedy heuristic, column generation-based algorithm dan two-phase Benders decomposition-based algorithm. Eksperimen mereka lakukan dengan mensimulasikan permasalahan 20 pelabuhan dan 100 kapal.

Pada penelitian ini model penjadwalan dan penentuan rute pengiriman tidak hanya dimodelkan dan disimulasikan tetapi juga diimplementasikan untuk permasalahan nyata. Berbeda dengan model serupa yang dibangun oleh Bronmo et al. [3] dengan pemrograman linier, maka model pada penelitian ini menggunakan model pemrograman non-linear disebabkan permasalahan di dunia nyata sulit didekati menggunakan model pemrograman linier. Model yang dibuat digunakan untuk menyelesaikan permasalahan penentuan rute pelayaran di Indonesia Timur dengan karakteristik banyaknya pelabuhan yang dikunjungi dan batasan lain yang kompleks. Hal ini mengakibatkan beberapa batasan perlu ditambahkan dan waktu eksekusi model perlu dipertimbangkan agar efisien. Batasan-batasan yang membuat penelitian ini berbeda dengan penelitian sebelumnya, seperti Bronmo et al. [3] dan 
Agarwal dan Ergun [5], adalah waktu kunjungan antar satu kapal dengan kapal berikutnya pada satu pelabuhan tujuan memiliki batasan minimal. Hal ini disebabkan oleh jumlah barang yang diangkut oleh satu kapal akan menjadi kecil jika waktu kunjungan antar kapal terlalu dekat, dan hal ini tidak diinginkan oleh pihak perusahaan pelayaran. Selain itu ada batasan jumlah pelabuhan maksimum yang dapat dikunjugi dalam satu rute pelayaran.

\section{Metode Penelitian}

\section{Pengembangan Model}

Model pada penelitian ini menggunakan pengembangan model VRPTW (Vehicle routing problem with time windows). Berbeda dengan model VRPTW pada umumnya dimana time windows adalah batasan waktu kedatangan dan keberangkatan dari alat transportasi, maka pada model di penelitian ini time windows (TW) lebih longgar yaitu batas waktu perjalanan kapal dan waktu minimal kunjungan antara satu kapal dengan kapal berikutnya pada satu pelabuhan tujuan. Selain itu ada batasan jumlah kunjungan pada satu pelabuhan yang disebut sebagai jumlah call. Batasan jumlah call ini dimodelkan dengan memecah lokasi tersebut sesuai jumlah call. Contoh untuk Makasar yang memiliki jumlah call 15 kali, sehinga diberi kode MKS.01 hingga MKS.15 dan satu kode mewakili satu kali kunjungan. Selain itu model juga mempertimbangkan batasan maksimal pelabuhan yang dapat dikunjungi dalam satu rute pelayaran. Rincian kendala ditetapkan perusahaan pelayaran pada model ini dapat diuraikan sebagai berikut: (a) Waktu kunjungan setiap lokasi yang sama berjeda minimal 3 hari. Perusahaan memiliki kebijakan jeda minimal 3 hari antar pengunjungan pelabuhan yang sama. Hal ini mengakibatkan tanggal kunjungan tiap lokasi yang sama harus terpaut minimal 3 hari antara satu dengan yang lainnya. (b) Jangka waktu satu bulan. Jangka waktu penjadwalan untuk satu bulan. Hal ini berarti setiap rute tidak boleh melebihi satu bulan untuk kembali ke Surabaya. Satu bulan menggunakan 31 hari. (c) Batasan maksimal lima lokasi yang dikunjungi. Perusahaan memiliki kebijakan dimana dalam satu rute pelayaran maksimal hanya dapat mengunjungi empat hingga lima lokasi. (d) Kode huruf yang sama tidak boleh bersebelahan. Pelayaran tidak memungkinkan mengunjungi pelabuhan yang sama secara berurutan. Sebagai contoh tidak diperkenankan adanya rute pelayaran MKS.01 dilanjutkan ke MKS.07.

Penyelesaian model penjadwalan dan penentuan rute pelayaran kapal menggunakan insertion heuristic sebagai solusi awal dan perbaikan solusi menggunakan metode simulated annealing. Metode insertion heuristic menggunakan metode yang dikembangkan oleh Solomon [6]. Konsep algoritma ini adalah dengan menyisipkan pelabuhan yang belum dijadwalkan ke dalam jadwal yang sudah ada dengan mempertimbangkan batasan waktu yang dipunyai dan batasan waktu minimal antar kunjungan. Penyisipan bisa dilakukan baik di awal, di tengah atau di akhir rute yang sudah dibuat dan dipilah penyisipan dengan jarak terpendek. Rincian algoritma insertion heuristic dapat dilihat pada Gambar 1.

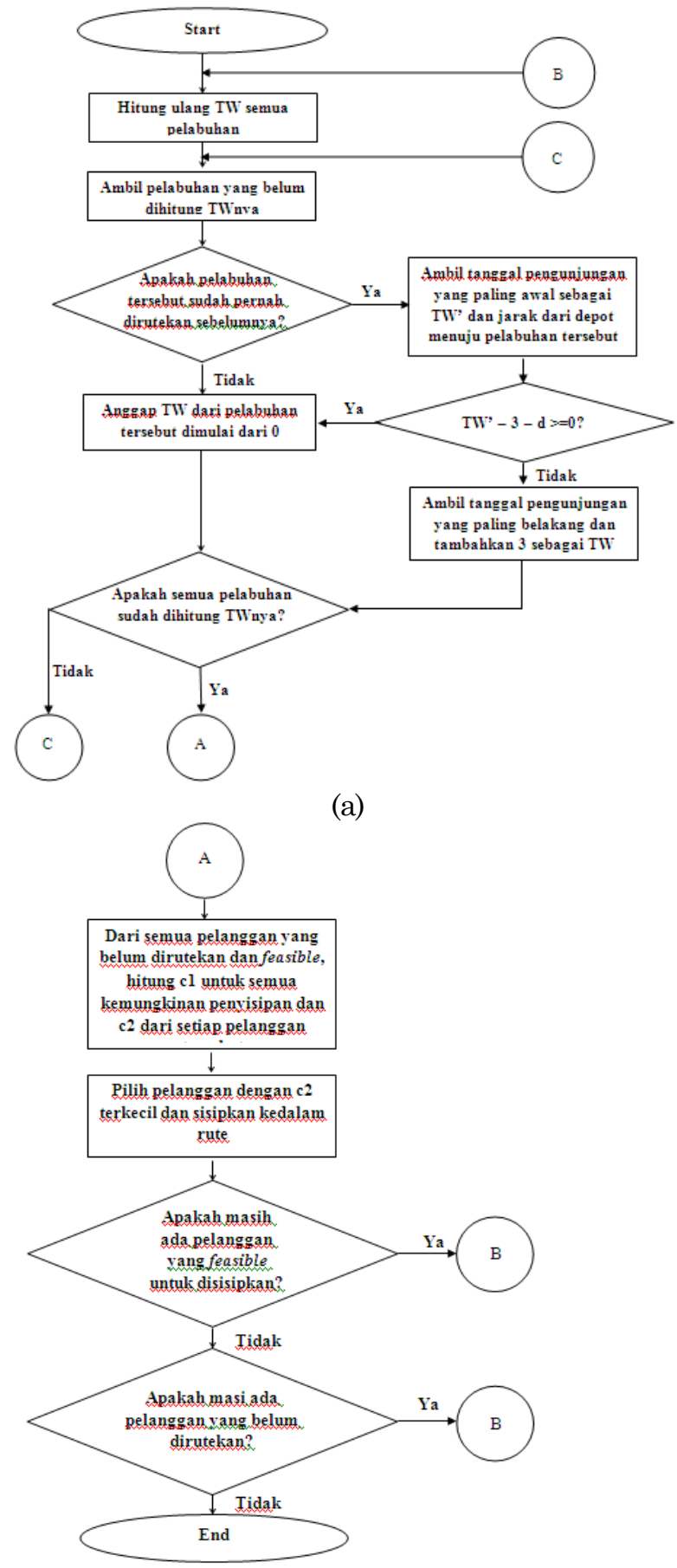

(b)

Gambar 1. Insertion heuristic 
Pemilihan pelanggan yang akan disisipkan ke dalam rute juga memiliki kriteria pemilihan. Metode insertion heuristic menggunakan dua kriteria, yaitu $c_{1}(i, u, j)$ dan $c_{2}(i, u, j)$ pada setiap iterasi untuk menyisipkan pelanggan $u$ diantara pelanggan $i$ dan $j$ yang bersebelahan pada rute. Pertama, hitung $c_{1}(i, u, j)$ untuk setiap pelanggan yang belum ditentukan rutenya, dan dari setiap pelanggan tersebut masing-masing dicarilah posisi penyisipan yang layak dan memiliki $c_{1}(i, u, j)$ yang paling kecil. Selanjutnya, pelanggan $u$ yang terbaik untuk disisipkan ke dalam rute dipilih dengan menghitung $c_{2}(i, u, j)$ yang optimal. Kriteria untuk penghitungan $c_{1}(i, u, j)$ dan $c_{2}(i, u, j)$ sendiri ada tiga kriteria, yaitu:

(a) Tipe yang ini berusaha untuk memaksimalkan keuntungan yang didapat dari menyisipkan pelanggan kedalam rute daripada membentuk rute yang sudah jadi.

$c_{11}(i, u, j)=d_{i u}+d_{u j}-\mu d_{i j}$

dimana $\mu \geq 0$;

$c_{12}(i, u, j)=b_{j u}-b_{j}$,

$c_{1}(i, u, j)=\alpha_{1} c_{11}(i, u, j)+\alpha_{2} c_{12}(i, u, j)$

dimana $\alpha_{1}+\alpha_{2}=1$ dan

$\alpha_{1} \geq 0, \alpha_{2} \geq 0$

$c_{2}(i, u, j)=\lambda d_{0 u}-c_{1}(i, u, j)$,

dimana: $\lambda \geq 0$

Sebagai contoh apabila $\mu=\alpha_{1}=\lambda=1$ dan $\alpha_{2}=0$, maka $c_{2}(i, u, j)$ adalah jarak yang diperoleh dari menyisipkan pelanggan $u$ diantara pelanggan $i$ dan $j$. Posisi penyisipan yang paling baik adalah posisi yang meminimalkan kombinasi dari jarak dan waktu penyisipannya.

(b) Tipe kedua heuristik ini bertujuan untuk memilih pelanggan yang biaya penyisipannya meminimumkan total jarak dan waktu.

$c_{1}(i, u, j)=\beta_{1} R_{d}(u)+\beta_{2} R_{t}(u)$

dimana $\beta_{1}+\beta_{2}=1$ dan $\beta_{1} \geq 0, \beta_{2} \geq 0$

(c) Tipe ketiga heuristik ini juga memperhitungkan aspek seberapa cepat harus dilayaninya seorang pelanggan.

$c_{13}(i, u, j)=l_{u}-b_{u}$

$c_{1}(i, u, j)=\alpha_{1} c_{11}(i, u, j)+\alpha_{2} c_{12}(i, u, j)+$

$\alpha_{3} c_{13}(i, u, j)$

dimana: $\alpha_{1}+\alpha_{2}+\alpha_{3}=1$ dan $\alpha_{1} \geq 0, \alpha_{2} \geq 0$,

$\alpha_{3} \geq 0 ; c_{2}(i, u, j)=c_{1}(i, u, j)$

Nilai $c_{11}$ dan $c_{12}$ sama dengan yang ada pada tipe pertama, sedangkan $c_{13}$ menunjukkan interval waktu antara dimulainya pelanggan $u$ dan waktu terakhir kendaraan boleh memulai pelayaran, dimana:

$b_{j \prime} \quad:$ waktu pelayaran di pelabuhan $j$ sebelum disisipi

$b_{j u} \quad:$ waktu dimulainya pelayaran yang baru pada pelanggan $j$, ketika pelanggan $u$ disisipkan ke dalam rute

$j \quad$ : urutan pelabuhan yang sudah terdapat di rute tersebut $(j=0,1, \ldots)$

$d_{i u} \quad$ : waktu tempuh dari pelabuhan $i$ ke pelabuhan $u$

$c_{1}(i, u, j)$ : kriteria pertama penghitungan jarak jika rute pelabuhan $u$ disisipkan di antara pelabuhan $i$ dan $j$

$c_{2}(i, u, j)$ : kriteria kedua penghitungan jarak jika rute pelabuhan $u$ disisipkan di antara pelabuhan $i$ dan $j$

$R_{d}(u) \quad$ : total jarak dari rute ketika pelanggan $u$ disisipkan

$R_{t}(u) \quad$ : total waktu dari rute ketika pelanggan $u$ disisipkan

$l_{u} \quad:$ waktu paling akhir kapal boleh melakukan pelayaran dari pelabuhan $u$

$b_{u} \quad$ : waktu paling awal kapal tiba di pelabuhan $u$

Solusi awal yang didapatkan menggunakan insertion heuristic akan diperbaiki kinerjanya menggunakan metode simulated annealing (SA). Metode ini digunakan dikarenakan efektif dalam menyelesaikan permasalahan penentuan rute kapal seperti dinyatakan oleh Kosmas dan Vlachos [7]. Algoritma simulated annealing yang digunakan pada penelitian ini dijabarkan pada Gambar 2.

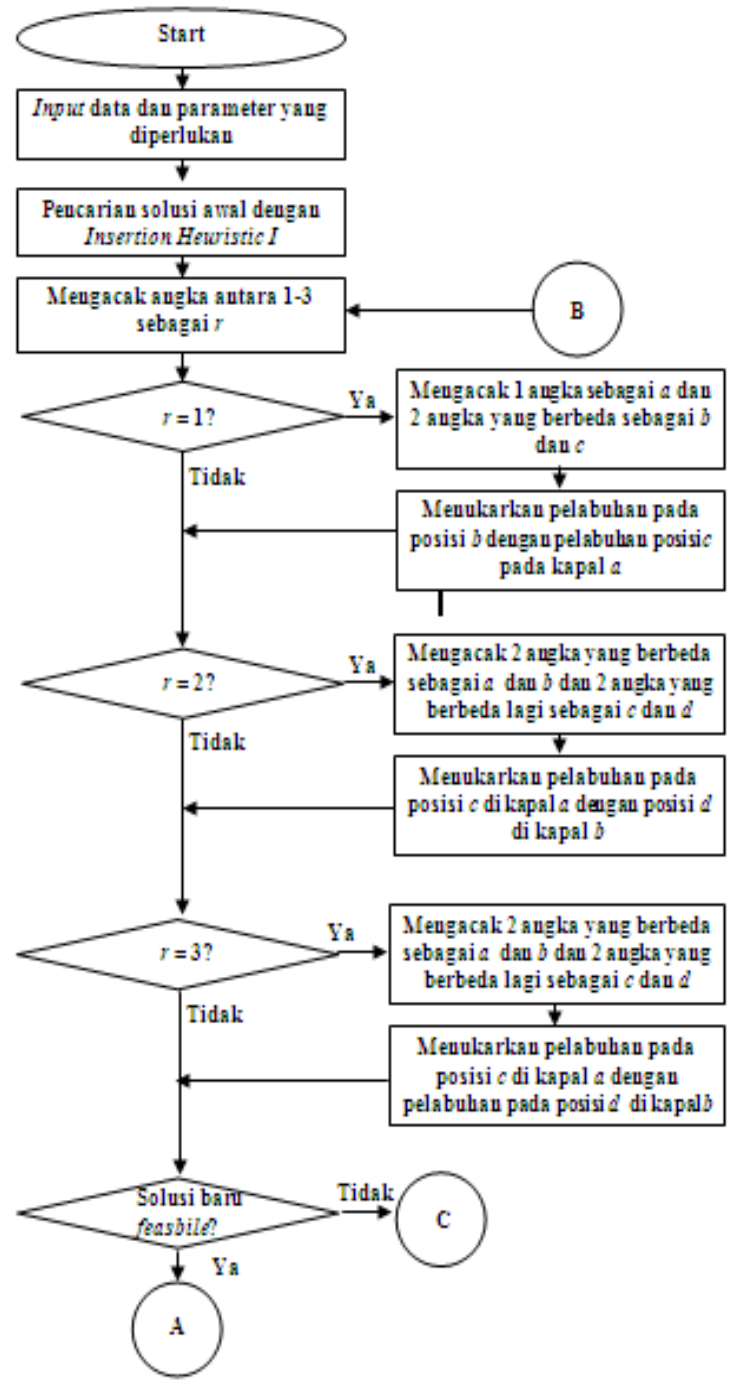

(a) 


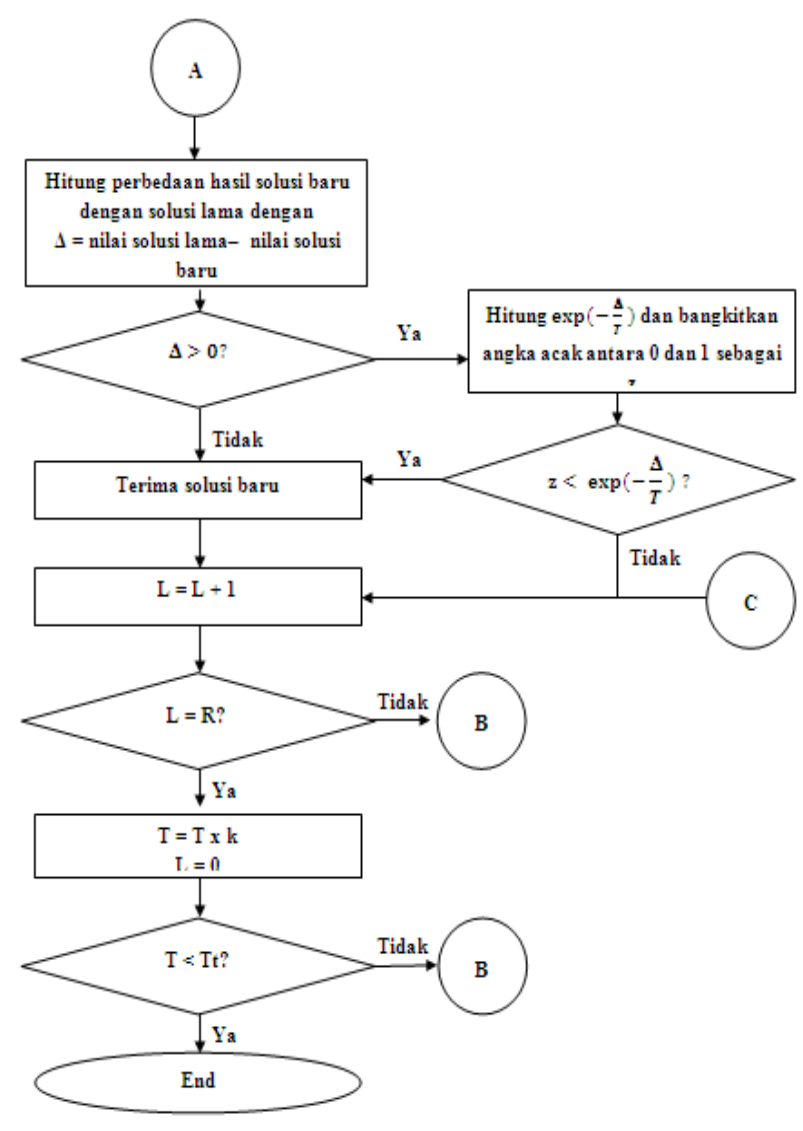

(b)

Gambar 2. Algoritma simulated annealing

Metode penukaran (neighborhood search) menggunakan tiga metode pencarian dimana ketiga metode pencarian tersebut dipilih secara acak pada setiap iterasinya. Ketiga metode pencarian yang digunakan mengacu pada Caric et al. [8].

\section{Neighborhood Search 1}

Penukaran neighborhood search 1 merupakan metode yang menukarkan dua pelabuhan pada satu kapal yang sama atau disebut dengan intra route exchange. Pencarian ini terlebih dahulu mencari kapal mana yang akan dipilih dan kemudian mengacak dua angka. Hasil pada kedua angka yang terpilih tersebut kemudian ditukar posisinya. Contoh metode penukaran ini dapat dilihat pada Gambar 3.

\section{Neighborhood Search 2}

Penukaran neighborhood search 2 adalah metode yang menukarkan posisi dari satu pelabuhan dari sebuah kapal dengan satu pelabuhan dari kapal yang berbeda atau disebut juga dengan metode inter route exchange. Pencarian ini pertama mengacak dua kapal yang akan dipilih. Masing-masing kapal kemudian dibangkitkan lagi satu angka acak untuk menentukan kapal yang akan ditukarkan dan kemudian ditukarkan posisinya. Gambar 4 merupakan contoh neighborhood search 2.

\section{Neighborhood Search 3}

Pada metode penukaran ini akan dilakukan pemindahan satu pelabuhan dari sebuah kapal dan menyisipkannya ke kapal yang berbeda. Penukaran ini pertama mengacak dua kapal yang akan dipilih. Kapal pertama kemudian dibangkitkan angka acak untuk memilih kapal mana yang akan diambil pelabuhannya. Kapal kedua kemudian dibangkitkan pula angka acak untuk memilih posisi mana yang akan disisipi pelabuhan dari kapal pertama. Gambar 5 merupakan contoh neighborhood search 3.

\section{Hasil dan Pembahasan}

Data diambil berdasarkan data sekunder dan hasil wawancara. Beberapa data yang diperlukan diantaranya adalah data waktu tempuh, dan data waktu pelayanan di pelabuhan. Contoh data tersebut dapat dilihat di Tabel 1 dan Tabel 2.

Penjadwalan pada perusahaan dibuat berdasarkan kebijakan yang telah dijelaskan sebelumnya. Pertama dimana adanya jumlah call time yang menandakan tiap pelabuhan pada Indonesia bagian Timur harus dikunjungi berapa kali pada setiap bulannya. Kedua yaitu jeda minimal 3-4 hari pada setiap pengunjungan pelabuhan yang sama. Jeda ini berlaku untuk semua pelabuhan kecuali pada Makassar, dimana hal ini dikarenakan Makassar merupakan salah satu pelabuhan utama yang menghubungkan seluruh Indonesia. Ketiga dimana sebuah kapal tidak diperbolehkan untuk mengunjungi lebih dari empat atau lima pelabuhan sebelum kembali ke Surabaya. Kebijakan ketiga ini supaya sebuah kapal tidak akan memiliki deviasi yang terlalu besar untuk kembali ke Surabaya yang dikarenakan cuaca dan sebagainya.

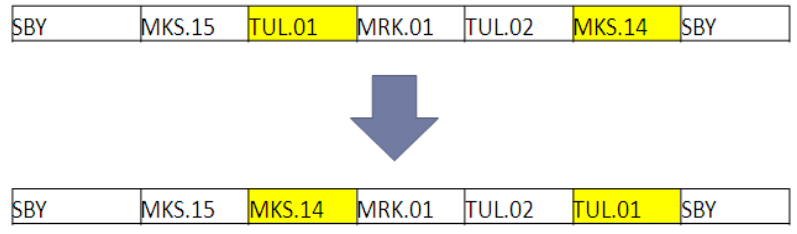

Gambar 3 Contoh neighborhood search 1

\begin{tabular}{|l|l|l|l|l|l|l|}
\hline SBY & MKS.15 & TUL.01 & MRK.01 & TUL.02 & MKS.14 & SBY \\
\hline SBY & SRI.01 & JYP.01 & SRI.02 & FAK.01 & MKS.01 & SBY \\
\hline \multicolumn{1}{|l}{} \\
\hline SBY & FAK.01 & TUL.01 & MRK.01 & TUL.02 & MKS.14 & SBY \\
\hline SBY & SRI.01 & JYP.01 & SRI.02 & MKS.15 & MKS.01 & SBY \\
\hline
\end{tabular}

Gambar 4. Contoh neihgborhood search 2 


\begin{tabular}{|l|l|l|l|l|l|l|}
\hline SBY & MKS.13 & MRK.02 & TUL.03 & BAU.01 & MKS.12 & SBY \\
\hline SBY & BIA.01 & NBR.01 & BIA.02 & MNK.01 & SBY & \\
\hline
\end{tabular}

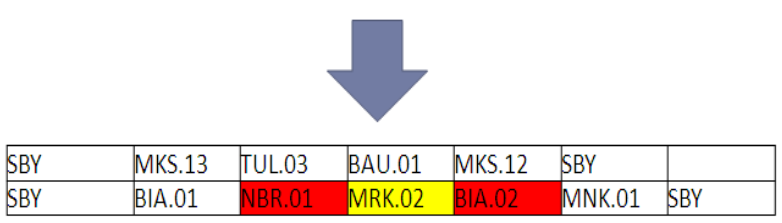

Gambar 5. Contoh neighborhood search 3

Tabel 1. Contoh data waktu tempuh (hari)

\begin{tabular}{lcccc}
\hline \multicolumn{1}{c}{ Dari/Ke } & Surabaya & Makassar & Bau-Bau & Bitung \\
\hline Surabaya & - & 2 & 3 & 5 \\
Makassar & 2 & - & 1 & 4 \\
Bau-Bau & 3 & 1 & - & 3 \\
Bitung & 5 & 4 & 3 & - \\
\hline
\end{tabular}

Tabel 2. Contoh data waktu pelayanan

\begin{tabular}{lc}
\hline \multicolumn{1}{c}{ Pelabuhan (Kota) } & Waktu Pelayanan (Hari) \\
\hline Makassar & 1 \\
Bau-Bau & 3 \\
Bitung & 1 \\
Ternate & 3 \\
\hline
\end{tabular}

Tabel 3. Solusi awal

\begin{tabular}{|c|c|c|c|c|c|c|}
\hline SBY & MKS.15 & TUL.01 & MRK.01 & TUL.02 & MKS.14 & SBY \\
\hline 1 & 3 & 7 & 12 & 18 & 24 & 27 \\
\hline SBY & SRI.01 & JYP.01 & SRI.02 & FAK.01 & MKS.01 & SBY \\
\hline 1 & 7 & 10 & 15 & 19 & 25 & 28 \\
\hline SBY & MKS.13 & MRK.02 & TUL.03 & BAU.01 & MKS.12 & SBY \\
\hline 1 & 3 & 9 & 15 & 20 & 24 & 27 \\
\hline SBY & BIA.01 & NBR.01 & BIA.02 & MNK.01 & SBY & \\
\hline 1 & 7 & 11 & 15 & 19 & 28 & \\
\hline SBY & NBR.02 & BIA.03 & KAI.01 & TUL.04 & MKS.11 & SBY \\
\hline 1 & 8 & 12 & 18 & 21 & 27 & 30 \\
\hline SBY & MKS.10 & KAI.02 & FAK.02 & TIM.01 & MKS.09 & SBY \\
\hline 1 & 3 & 8 & 11 & 15 & 23 & 26 \\
\hline SBY & TIM.02 & BAU.02 & TIM.03 & MKS.08 & SBY & \\
\hline 1 & 7 & 14 & 20 & 28 & 31 & \\
\hline SBY & MNK.02 & SRG.01 & BIT.01 & BAU.03 & MKS.07 & SBY \\
\hline 1 & 7 & 11 & 16 & 23 & 27 & 30 \\
\hline SBY & BIT.02 & TER.01 & SRG.02 & MKS.06 & SBY & \\
\hline 1 & 6 & 11 & 16 & 25 & 28 & \\
\hline SBY & TER.02 & BIT.03 & TER.03 & MKS.05 & SBY & \\
\hline 1 & 6 & 11 & 16 & 25 & 28 & \\
\hline SBY & SRG.03 & MNK.03 & NBR.03 & MKS.04 & SBY & \\
\hline 1 & 6 & 11 & 16 & 26 & 29 & \\
\hline SBY & BAU.04 & TIM.04 & MRK.03 & MKS.03 & SBY & \\
\hline 1 & 4 & 10 & 16 & 25 & 28 & \\
\hline SBY & MKS.02 & SBY & & & & \\
\hline 1 & 3 & 6 & & & & \\
\hline SBY & JYP.02 & SRG.04 & SBY & & & \\
\hline 6 & 13 & 20 & 29 & & & \\
\hline SBY & JYP.03 & SBY & & & & \\
\hline 9 & 16 & 27 & & & & \\
\hline SBY & MRK.04 & SBY & & & & \\
\hline 12 & 19 & 30 & & & & \\
\hline SBY & JYP.04 & SBY & & & & \\
\hline 12 & 19 & 30 & & & & \\
\hline SBY & BIT.04 & SBY & & & & \\
\hline 14 & 19 & 28 & & & & \\
\hline SBY & TER.04 & SBY & & & & \\
\hline 14 & 19 & 28 & & & & \\
\hline
\end{tabular}

Tabel 4. Hasil akhir SA lima replikasi

\begin{tabular}{lccccccc}
\hline Replikasi & 1 & 2 & 3 & 4 & 5 & Rata-rata & StDev \\
\hline Nilai Akhir & 248 & 245 & 251 & 243 & 251 & 247,6 & 3,57 \\
\hline
\end{tabular}

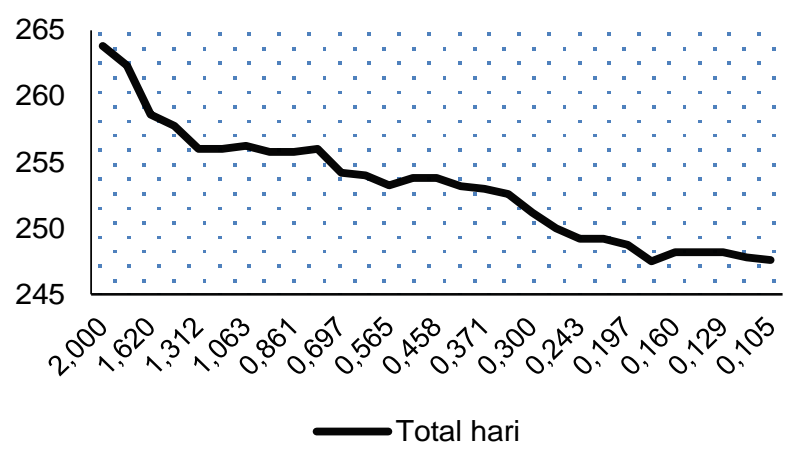

Gambar 6. Rata-rata solusi terbaik SA

Penjadwalan pada perusahaan untuk bagian Timur belum memiliki jadwal yang tetap, sehingga tiap bulannya rute yang digunakan hampir semuanya berbeda.

Penjadwalan rute yang digunakan oleh perusahaan di bulan April 2016 memiliki total waktu tempuh sebesar 297 hari dan jumlah kapal yang digunakan sebanyak 21 kapal.

Metode penyelesaian solusi awal dengan insertion heuristic menghasilkan solusi seperti pada Tabel 3. Total waktu perjalanan yang ditempuh selama sebulan dari hasil insertion heuristic yaitu sebesar 264 hari. Tabel 3 menunjukkan angka dibawah kode huruf merupakan waktu tiba di lokasi tersebut, sebagai contoh pada Kapal 1 lokasi MKS.15 terdapat angka 3 dibawahnya. Hal ini menunjukkan bahwa MKS.15 dikunjungi pada tanggal 15. Khusus untuk SBY yang terletak paling awal rute kapal, angka dibawahnya adalah waktu berangkat dari kapal tersebut dari Surabaya.

Parameter simulated annealing yang digunakan pada penelitian ini adalah sebagai berikut:

suhu awal $\left(T_{0}\right)=2$

suhu akhir $\left(T_{t}\right)=0,1$

faktor reduksi suhu $(\mathrm{k})=0,9$

jumlah looping $(L)=100$.

Sesuai dengan parameter yang digunakan, model akan melakukan total replikasi sebanyak 29 iterasi, dimana penurunan suhu terjadi sebanyak 29 kali dan pada setiap suhu dilakukan 100 iterasi. Model baru akan selesai mencari neighborhood solution sebanyak 2900 kali. Simulasi dijalankan sebanyak 5 kali dengan menggunakan software Microsoft Excel. Komputer yang digunakan memiliki OS Windows 7 Proffesional 32- bit dengan processor Intel(R) Core(TM)2Duo CPU @2,93GHz dan memory 1024 $M b$ RAM. Hasil akhir dari tiap simulasi dapat dilihat pada Tabel 4 . 
Tabel 5. Hasil dari simulasi keempat

\begin{tabular}{|c|c|c|c|c|c|c|}
\hline SBY & MKS.08 & TUL.02 & MRK.03 & TUL.01 & MKS.07 & SBY \\
\hline 1 & 3 & 7 & 12 & 18 & 24 & 27 \\
\hline SBY & SRI.01 & JYP.02 & MNK.01 & FAK.01 & SBY & \\
\hline 1 & 7 & 10 & 15 & 20 & 28 & \\
\hline SBY & MKS.03 & MRK.04 & TUL.03 & BAU.01 & MKS.12 & SBY \\
\hline 1 & 3 & 9 & 15 & 20 & 24 & 27 \\
\hline SBY & BIA.01 & NBR.03 & BIA.03 & BIT.04 & MKS.05 & SBY \\
\hline 1 & 7 & 11 & 15 & 20 & 28 & 31 \\
\hline SBY & NBR.01 & BIA.02 & KAI.01 & MKS.14 & SBY & \\
\hline 1 & 8 & 12 & 18 & 24 & 27 & \\
\hline SBY & MKS.10 & FAK.02 & KAI.02 & TIM.01 & MKS.06 & SBY \\
\hline 1 & 3 & 8 & 11 & 14 & 22 & 25 \\
\hline SBY & TIM.03 & BAU.03 & MKS.04 & SBY & & \\
\hline 1 & 7 & 14 & 18 & 21 & & \\
\hline SBY & MNK.02 & SRG.01 & BIT.03 & BAU.02 & MKS.11 & SBY \\
\hline 1 & 7 & 11 & 16 & 23 & 27 & 30 \\
\hline SBY & BIT.02 & TER.01 & SRG.04 & TER.03 & SBY & \\
\hline 1 & 6 & 11 & 16 & 21 & 30 & \\
\hline SBY & TER.04 & BIT.01 & TER.02 & SRG.03 & SBY & \\
\hline 1 & 6 & 11 & 16 & 21 & 30 & \\
\hline SBY & SRG.02 & MNK.03 & TIM.02 & TUL.04 & SBY & \\
\hline 1 & 6 & 11 & 17 & 22 & 30 & \\
\hline SBY & BAU.04 & TIM.04 & MRK.01 & MKS.01 & SBY & \\
\hline 1 & 4 & 10 & 16 & 25 & 28 & \\
\hline SBY & MKS.13 & SBY & & & & \\
\hline 1 & 3 & 6 & & & & \\
\hline SBY & JYP.01 & NBR.02 & SRI.02 & SBY & & \\
\hline 6 & 13 & 19 & 23 & 31 & & \\
\hline SBY & JYP.04 & SBY & & & & \\
\hline 9 & 16 & 27 & & & & \\
\hline SBY & MRK.02 & MKS.15 & SBY & & & \\
\hline 12 & 19 & 28 & 31 & & & \\
\hline SBY & JYP.03 & SBY & & & & \\
\hline 12 & 19 & 30 & & & & \\
\hline SBY & MKS.02 & SBY & & & & \\
\hline 14 & 16 & 19 & & & & \\
\hline SBY & MKS.09 & SBY & & & & \\
\hline 14 & 16 & 19 & & & & \\
\hline
\end{tabular}

Gambar 6 menunjukkan rata-rata solusi terbaik SA dari lima kali replikasi dari setiap suhu. Tampak terjadi penurunan rata-rata solusi terbaik dari suhu awal dan pada suhu 0,16 solusi sudah dalam kondisi konvergen. Hal ini menunjukkan bahwa metode SA yang digunakan menghasilkan solusi yang konsisten lebih baik dari satu suhu ke suhu yang lebih kecil dan pada suhu minimal yang ditetapkan solusi sudah konvergen.

Hasil terbaik dari lima running simulated annealing di atas dapat dilihat pada Tabel 5. Jadwal pada Tabel 5 menunjukkan bahwa pada penjadwalan yang dibuat menggunakan 19 unit kapal dengan jarak tempuh 243 hari. Sebagai contoh untuk kapal pertama jadwal kunjungan menempuh rute SBYMKS-TUL-MRK-TUL-MKS dan kembali ke SBY dengan keberangkatan mulai tanggal satu dan kembali tanggal 27 sehingga menempuh perjalanan selama 27 hari. Secara total terjadi penurunan waktu pelayaran sebesar 7,95\% dari solusi awal dan jika dibandingkan dengan jadwal yang dimiliki perusahaan saat ini terjadi penurunan sebesar $18,2 \%$. Selain itu jumlah kapal yang dipakai juga lebih sedikit dua buah kapal dibandingkan dengan jadwal yang disusun oleh perusahaan.

\section{Simpulan}

Penelitian ini mencoba menyusun jadwal dan rute pelayaran kapal dengan mempertimbangkan waktu kedatangan kapal dan jumlah kunjungan pada satu pelabuhan. Jumlah pelabuhan yang akan dikunjungi sebanyak 15 pelabuhan, tetapi dengan adanya kebutuhan kunjungan pada satu pelabuhan yang bisa lebih dari satu, maka jumlah yang lokasi yang dikunjungi sebanyak 62 lokasi. Penyelesaiaan dilakukan dengan menggunakan metode simulated annealing. Solusi menunjukkan bahwa terjadi penurunan waktu pelayaran sebesar $7,95 \%$ pada solusi akhir SA dibandingkan dengan solusi awal. Solusi akhir metode yang diusulkan lebih baik 18,2\% dibandingkan jadwal dan rute pelayaran yang dimiliki perusahaan saat ini. Penelitian ini masih menggunakan data waktu pelayaran yang bersifat konstan, akan lebih baik jika mempertimbangkan ketidakpastian waktu pelayaran dan pelayanan di pelabuhan. Selain itu metode lain slain SA dapat dipertimbangkan untuk menghasilkan solusi yang lebih baik dan waktu penyelesaian yang lebih cepat.

\section{Daftar Pustaka}

1. Christiansen, M., Fagerholt, K., Ronen, D., Ship Routing and Scheduling: Status and Perspectives, Transportation Science, 38(1), 2004, pp. 118.

2. Christiansen, M., Fagerholt, K., Nygreen, B., and Ronen, D., Ship Routing and Scheduling in The New Millenium, European Journal of Operational Research, 228, 2013, pp. 467-483.

3. Bronmo, G., Christiansen, M., and Nygreen, B., Ship Routing and Scheduling with Flexible Cargo Sizes, Journal of Operational Research Society, 58, 2007, pp. 1167-1177.

4. Korsvik J.E., Fagerholt K. and Laporte G., A Tabu Heuristic for Ship Routing and Scheduling, Journal of the Operational Research Society, 61, 2010, pp. 594-603.

5. Agarwal and Ergun, Ship Scheduling and Network Design of Cargo Routing in Liner Shipping, Transportation Science, 42(2), 2008, pp. 175-196.

6. Solomon, M.M., Algorithms for the Vehicle Routing and Scheduling Problems with Time Window Constraints, Operations Research, 35(2), 1987, pp. 254-265.

7. Kosmas, O.T., and Vlachos, D.S., Simulated Annealing of Optimal Ship Routing, Computers \& Operations Research, 39, 2012, pp. 576-581.

8. Caric, T., Galic, A., Fosin, J., Gold, H., and Reinholz A., A Modelling and Optimization Framework for Real-World Vehicle Routing Problems, I-tech, Vienna. 2008. 